\title{
THE STATE OF PLAY OF BUSINESS INNOVATION PROMOTION IN LITHUANIA: THEORETICAL, STRATEGIC AND STATISTICAL ASPECTS
}

\author{
Kristina BALKIENE \\ Mykolas Romeris University \\ Valakupiu 5, 10101 Vilnius, Lithuania \\ E-mail: kristinabalkiene@gmail.com
}

doi:10.13165/IE-13-7-2-07

\begin{abstract}
Insufficient business innovation activity in Lithuania shows a need to explore possible factors determining this state of play. It is assumed that lack of concrete and specifically targeted government actions or their efficiency is extremely important here. Thus, in order to analyse business innovation promotion in Lithuania, theoretical, strategic and statistical data are taken into consideration. This paper suggests the generalised theoretical system of business innovation determinants, analyses the statistics describing business innovation activity in Lithuania, and provides an assessment of the current Action Plan of Lithuanian Innovation Strategy for 2010-2020 from a business innovation promotion perspective.
\end{abstract}

JEL Classification: O31.

Keywords: business, innovation activity, innovation promotion, Lithuanian Innovation Strategy.

Reikšminiai žodžiai: verslas, inovacinè veikla, inovacijų skatinimas, Lietuvos inovacijų strategija.

\section{Introduction}

It is commonly agreed that innovation is the foundation of economic development $[15 ; 7 ; 4 ; 24]$ and the best way to respond to major societal challenges [6]. According to Joseph Schumpeter (1911), since innovation is essential for the economic development, a theory of economic development requires not simply a 'theory of the firm' but a 'theory of the innovating firm' [24].

Business innovation activity is defined here as a complex of creation, development and commercialisation processes of a new or significantly improved products, services, production methods or business organisation forms which brings higher added value to the market or better performance results inside an enterprise. The usage of new knowledge and entrepreneurial skills can be treated as an anchor of such activity. 
In the Innovation Union Communication (2010), the European Commission clearly highlighted the need to remove the remaining barriers for entrepreneurs to bring ideas to market ensuring better access to finance, particularly for SMEs, affordable intellectual property rights, smarter and more ambitious regulation and targets, faster setting of interoperable standards and strategic use of procurement budgets. An enhancement of business and science cooperation was also emphasised as essential to get more innovation out of research [6].

At national level, the Lithuanian Innovation Strategy for 2010-2020 underlined a necessity to reorient the country's economy towards the production of high added value products and services, where building an environment favourable for innovative business development plays a vital role.

However, the statistical data and different evaluation results do not show Lithuania's strengths in the field of business innovation activity. Therefore, the key problem discussed in this article is related to the insufficient business innovation results in Lithuania, which in the long run can cause non-competitive economy lagging behind the other EU countries. It is assumed that lack of concrete and specifically targeted government actions or their efficiency is extremely important here.

It can be noted that despite the growing popularity of innovation-related researches, the scientific discussions often contain separate factors or fields of innovation activity, while the explorations focused on the Lithuanian government actions to promote the development of innovative business sector as well as their coherence with factual business innovation performance results are still rare.

Former researches directed towards the issues concerned with the research problem referred above were performed by: Adekota A., Korsakienė R., Tvaronavičiene M., 2008 [1]: the survey on the approach of the Lithuanian companies towards innovations according to the economic conditions and public policy, underlining the limited government role in the field of innovation promotion; Melnikas B., 2003 [12], Kraujelyte A., Petrauskas R., 2007 [10], Vilys M., Aleksandravičius P., 2008 [25], Jakubavičius A., Vilys M., 2009 [9], Baležentis A., Balkienè K., 2011 [2]: the researches in the field of national innovation policy; Baležentis A., Žalimaite M., 2011 [3], Stripeikis, O., Ramanauskas J., 2011 [22]: the investigations related to the identification of innovation factors.

The purpose of this paper is to analyse the results of business innovation promotion in Lithuania, taking into account the evidence given by theoretical, strategic and statistical data.

Agreeably, the following goals are defined: (1) to examine different sources of literature describing the particularity of business innovation activity with the aim to identify its main causes and influencing factors; (2) to analyse the results of business innovation activity in Lithuania; (3) to assess the current action plan of the Lithuanian Innovation Strategy for 2010-2020 from a business innovation promotion perspective.

The object is business innovation activity in Lithuania.

The research methods used: systemic and comparative analysis of literature in order to summarise the main aspects of business innovation activity identified by different authors; quantitative analysis of statistical data, pointing out the factual situation of business innovation development in Lithuania; qualitative and quantitative content analysis used to assess national innovation policy actions focused on the promotion of business innovation. 
The outcomes of this article can be useful for further improvements of national strategic actions needed to develop and strengthen the innovative business sector in Lithuania.

\section{Particularity of Business Innovation Activity: Theoretical Approach}

Business innovation activity is a complex and multidimensional process depending on the variety of factors and their interaction within the company's internal or/and external environments.

Usually the specific activities by which business enterprises can develop or acquire innovation are grouped into two main categories as listed below:

- $\quad$ R\&D-oriented activities: (1) engagement in basic and applied research in order to acquire new knowledge and direct research towards specific inventions or modifications of existing techniques; (2) development of new product or process concepts or other new methods to assess their feasibility and viability, a stage that may involve: (a) development and testing; and (b) further research to modify the design or technical functions.

- $\quad$ other innovative non-R\&D activities that may enable the development of innovations or the ability to successfully adopt innovations developed by other firms or institutions: (3) identification of the new concepts for products, processes, marketing methods or organisational changes: (a) via its marketing side and relations with users; (b) via the identification of opportunities for commercialisation resulting from its own or others' basic or strategic research; (c) via its design and development capabilities; (d) by monitoring competitors; and (e) by using consultants; (4) acquisition of technical information or know-how and skills through engineering, design or other consultancy services; (5) development of human skills; (6) investments into equipment, software or intermediate inputs that embody the innovative work of others; (7) reorganisation of management systems and other business activities; (8) development of new marketing or selling methods [13].

According to Oslo Manual (1996), the following main reasons of business innovation activity are identified via its economic objectives in terms of products and markets [14]:

replace products being phased out;

extend product range: within and outside main product field;

develop environmentally friendly products;

maintain or increase market share;

open up new markets: abroad or new domestic target groups;

improve production flexibility;

- lower production costs by: reducing unit labour costs; cutting the consumption of materials or energy consumption; reducing the reject rate; reducing product design costs; reducing production lead times;

- improve product quality;

- improve working conditions;

- reduce environmental damage.

It is obvious that the objectives of business innovation activity are oriented towards both quantitative and qualitative results that are often summarised in positive effects such as competitiveness, development and productivity. 
However, enterprises innovate in a non-isolated environment and are affected by different positive and negative factors that can determine their business success or failure. Oslo Manual (1996) groups these factors into: (a) various information sources assisting the innovation processes and (b) economic and other factors that may hamper the innovation activity (Table 1) [14].

Table 1. Factors influencing innovation activity

\begin{tabular}{|c|c|c|}
\hline \multirow[t]{4}{*}{$\begin{array}{l}\text { Assisting } \\
\text { factors }\end{array}$} & \multirow{4}{*}{$\begin{array}{l}\text { Information } \\
\text { sources } \\
\text { (internal and } \\
\text { external) }\end{array}$} & $\begin{array}{l}\text { Internal sources within the firms or business group: in-house R\&D; } \\
\text { marketing; production; other }\end{array}$ \\
\hline & & $\begin{array}{l}\text { External market/commercial sources: competitors; acquisition } \\
\text { of embodied and disembodied technology; clients or customers; } \\
\text { consultancy firms; suppliers of equipment, materials, components } \\
\text { and software }\end{array}$ \\
\hline & & $\begin{array}{l}\text { Educational/research institutions: higher education institutions; } \\
\text { government research institutes; private research institutes }\end{array}$ \\
\hline & & $\begin{array}{l}\text { Generally available information: patent disclosures; professional } \\
\text { conferences, meetings and journals; fairs and exhibitions }\end{array}$ \\
\hline \multirow{18}{*}{$\begin{array}{l}\text { Hampering } \\
\text { factors }\end{array}$} & \multirow{4}{*}{$\begin{array}{l}\text { Economic } \\
\text { factors }\end{array}$} & Excessive perceived risks \\
\hline & & Cost too high \\
\hline & & Lack of appropriate sources of finance \\
\hline & & Pay-off period of innovation too long \\
\hline & \multirow{8}{*}{$\begin{array}{l}\text { Enterprise } \\
\text { factors }\end{array}$} & Innovation potential (R\&D, design, etc.) insufficient \\
\hline & & Lack of skilled personnel \\
\hline & & Lack of information on technology \\
\hline & & Lack of information on markets \\
\hline & & Innovation expenditure hard to control \\
\hline & & Resistance to change in the firm \\
\hline & & Deficiencies in the availability of external services \\
\hline & & Lack of opportunities for cooperation \\
\hline & \multirow{6}{*}{$\begin{array}{l}\text { Other rea- } \\
\text { sons }\end{array}$} & Lack of technological opportunity \\
\hline & & Lack of infrastructure \\
\hline & & No need to innovate due to earlier innovations \\
\hline & & Weakness of property rights \\
\hline & & Legislation, norms, regulations, standards, taxation \\
\hline & & Customers unresponsive to new products and processes \\
\hline
\end{tabular}

Source: compiled according to the Oslo Manual (1996)

Additionally, the following elements of the general institutional environment affect business activity which is also essential for innovation: basic educational system for the general population; the university system; specialised technical training system; science and research base; common pools of codified knowledge, such as publications and various standards; innovation and other policies that influence innovation by firms; legislative and other governmental settings; financial institutions; market accessibility; industry structure and competitive environment [13].

The external environment of innovation also refers to such factors as: knowledge and competence base for innovation; incentives for investment into knowledge and en- 
trepreneurial activity; demand and markets; rules and regulations, organisational forms and communication between actors in innovation processes: businesses, the public sector, academia, civil society and individuals; specialised resources for the development of technology, methods, organisation or processes [23].

In view of the wide variety of innovation factors indicated by different sources, it is possible to suggest a generalised theoretical system of business innovation determinants (Figure 1) that can be divided into two main groups:

- Factors operating in company's internal environment: (1) human resources (their creativity, innovativeness, skills and qualification); (2) financial resources (internal financial possibilities to be engaged in the innovation activity); (3) knowledge and technologies; (4) organisational structure and management (focus on innovation not only in technological, but also in non-technological processes within the company).

- External environment factors: (1) education system (formal and informal); (2) public policy (strategic priorities and actions); (3) science and research system; (4) infrastructure consisting of various institutions necessary for business operation as well as information and communication technologies (ICT); (5) regulation system (legislation, standards and other regulations such as taxation or rules concerned with protection of intellectual property rights); (6) market factors.

Figure 1. Theoretical system of factors influencing business innovation activity

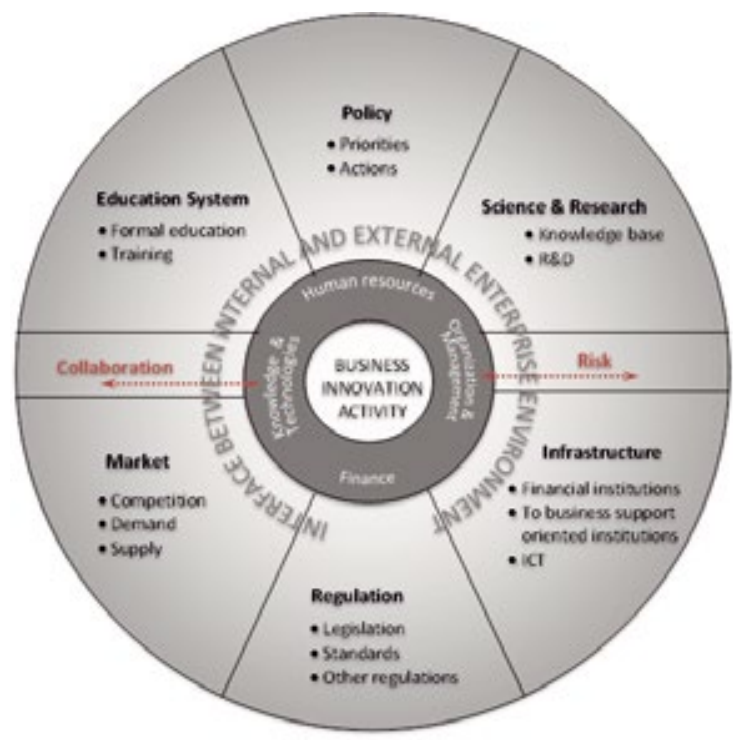

Source: compiled by author

It should be noted that the factors of collaboration and risk are attributed to both business internal and external environments inside the system under consideration. In 
terms of collaboration, the enterprise's openness to cooperate with other partners and involvement in different business networks plays a crucial role for the development of innovation activity and business internationalisation. However, the common collaboration culture of the country (for instance, the traditions and opportunities of business and science collaboration) is also a significant factor influencing business behaviour.

Regarding the risk factor, the preconditions for negative impact on business innovation performance can occur both inside and outside the company and usually are difficult to anticipate. According to Drucker (1959), to try to eliminate risk is futile. Risk is inherent in the commitment of present resources to future expectations. The attempt to eliminate risks or to minimise them can only make them irrational and unbearable $[5, \mathrm{p} 5]$.

However, despite the above discussions, a set of innovation factors may vary according to the type of innovation activity and different conditions within or outside business environment. It can be assumed that these factors strongly depend on the following aspects:

- at business level: the size and age of the enterprise; type of activity; market share and segment.

- at country level: economic, social, technological conditions in the country; public policies.

Thus, in summary, it is important to highlight the need for deeper studies justifying the link between different innovation factors and internal as well as external peculiarities of business.

\section{Business Innovation Activity in Lithuania: Statistical Evidence}

According to the statistical data, the innovation activity in Lithuania's business sector remains insufficient and does not show a clear growth trend. In 2008-2010, only around one-third of all Lithuania's enterprises were engaged in innovation activity (Figure 2). However, it is important to note here, that the turnover of these innovative enterprises amounted to $65.8 \%$ of total business turnover. Moreover, the enterprises engaged in innovation activity employed $51.2 \%$ of all business sector employees [20].

Figure 2. The share of business enterprises engaged in innovation activity

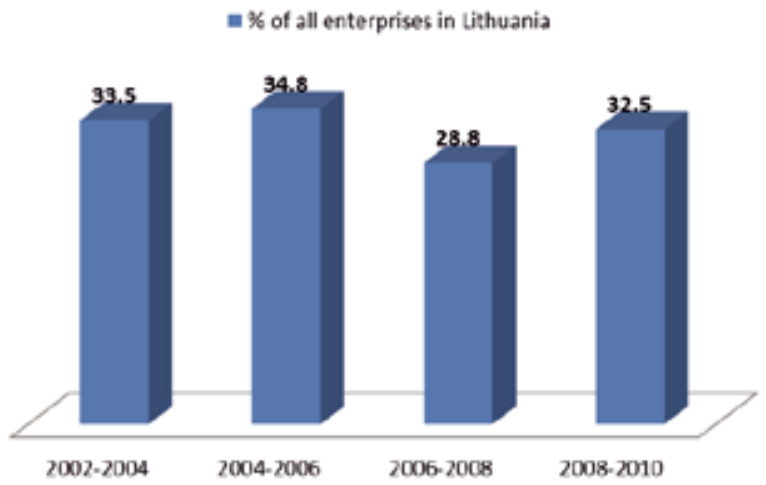

Source: compiled by the author according to the data provided by the Statistics Lithuania [21] 
In general, it can be seen that large enterprises are more active in the innovation activity than small or medium-sized enterprises: in 2008-2010, 69.6\% of all large enterprises were engaged in innovation activity, while only $27.9 \%$ of the small and $43.1 \%$ of the medium-sized enterprises innovated at the same time [19].

Taking into account the share of innovative enterprises operating in different fields of economic activity, the information and communication sector (i.e. publishing activities; video and television programme production; programming and broadcasting activities; telecommunications; computer programming; etc.) can be regarded as the most innovative in Lithuania: $62.4 \%$ of all enterprises in this field were engaged in innovation activity (Figure 3 ). However, innovation activity in traditional manufacturing industries, often named as the foundation of Lithuania's economy, still needs to be enhanced significantly: only $32 \%$ of all manufacturing enterprises were innovative.

Figure 3. A share of innovative enterprises by economic activity

$=\%$ of all Lithuania's enterprises in the given sector (2008-2010)

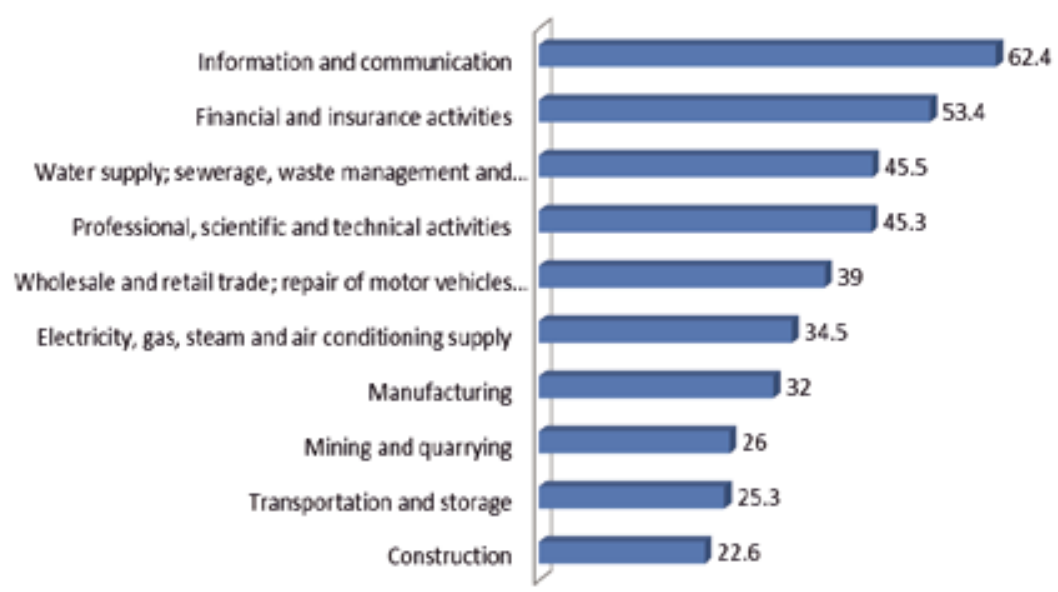

Source: compiled by the author according to the data provided by the Statistics Lithuania [21]

It is also worth mentioning that the Lithuanian Innovation Strategy designated the following manufacturing industries as creating high added value and competitive in the international market: manufacture of food products and beverages; manufacture of wood and wood products; manufacture of furniture; manufacture of textiles; manufacture of chemicals, chemical products and chemical fibre [8]. However, taking into consideration the statistical data given in Figure 4, the largest number of innovative enterprises was identified in the fields of beverage manufacturing (69.6\% of all enterprises) and manufacturing of computer, electronic and optical products (68.2\%). At the same time, the least innovative were the sectors of wood (18.2\%) and leather (20\%) products. 
The State of Play Of Business Innovation Promotion in Lithuania: Theoretical, Strategic and Statistical Aspects

Figure 4. The share of innovative enterprises in different manufacturing industries

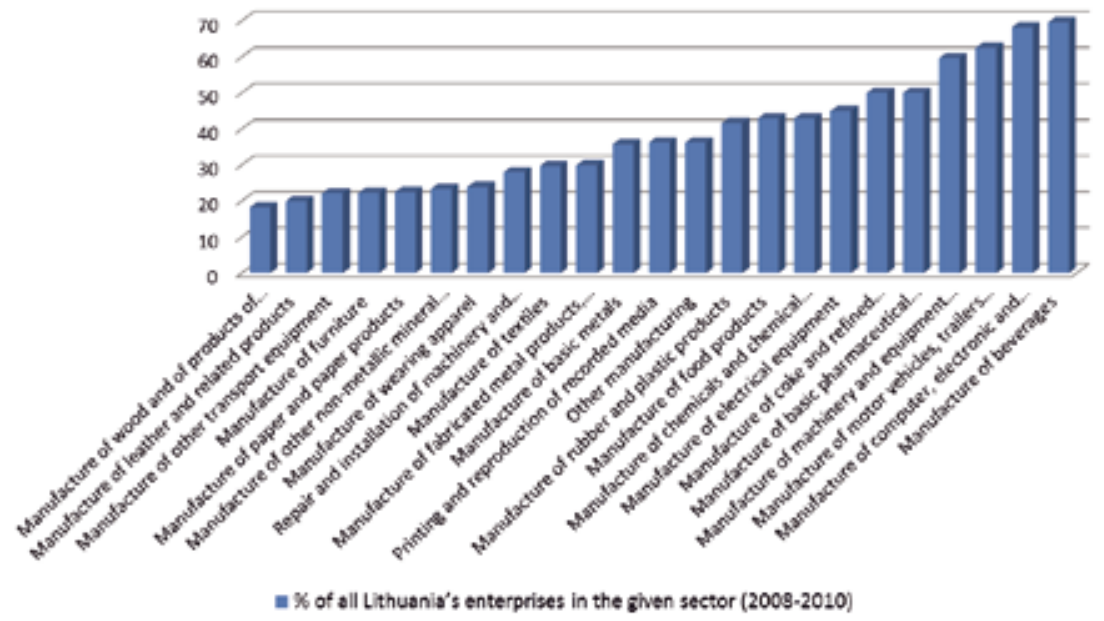

Source: compiled by the author according to the data provided by the Statistics Lithuania [21]

Low business R\&D intensity in Lithuania also gives evidence of limited abilities or motivation of companies to innovate. In 2011, business R\&D expenditure in Lithuania accounted for only $0.24 \%$ of GDP and was more than five times lower, compared to the EU27 average. More than half of total R\&D expenditure in Lithuania belongs to the higher education sector (Figure 5) [16].

Figure 5. Research and development expenditure by sectors (\% of GDP)

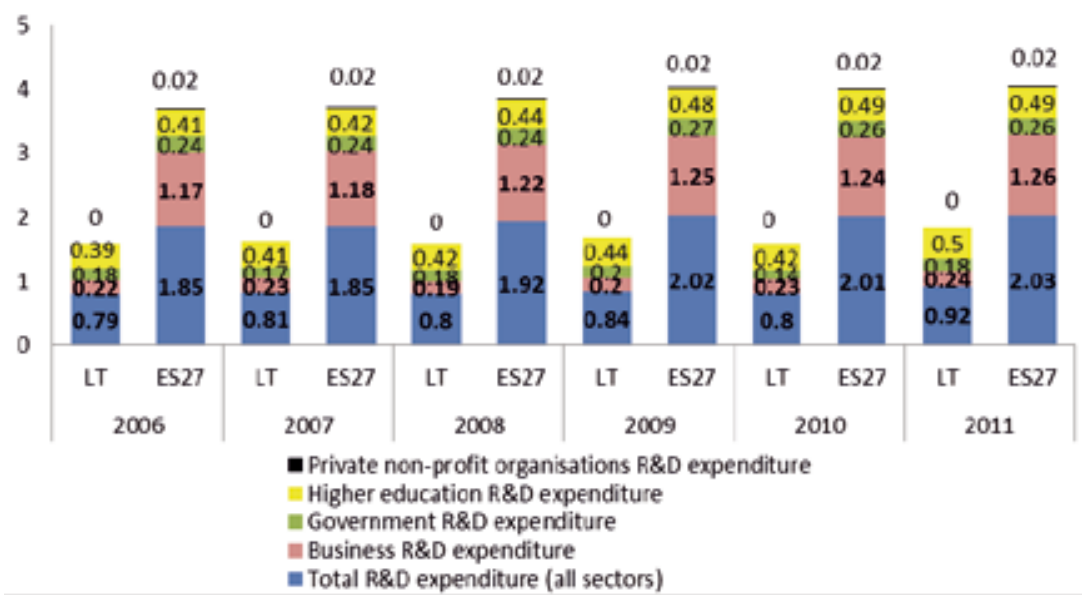

Source: compiled by the author according to the Eurostat data [16] 
Furthermore, it is stated that $77.4 \%$ of all business innovation expenditure was directed towards the acquisition of machinery, equipment and other facility, while only $1.6 \%$ of these expenses were related to the gain of external knowledge [19].

Additionally, weak orientation of private companies towards R\&D activities in Lithuania is also clear from the low number of researchers working in the business sector: in 2010 , only $13 \%$ of all researchers (i.e. 1771 researchers) were employed in the business sector [17].

Moreover, insufficient business innovation activity in Lithuania can also be caused by the lack of traditions in the field of common business and science cooperation. In 2008-2010, only $9.3 \%$ of all enterprises engaged in technological innovation activity collaborated with the public research institutions and only $14.9 \%$ of their partners were universities or other high education institutions [18]. The following cooperation partners of technological innovators were more popular here: suppliers of equipment, materials, components or software (36.9\%); clients or customers (33.1\%); competitors or other enterprises in the sector (22.9\%); consultants, commercial labs, or private R\&D institutes (21\%); other enterprises within the enterprise group (19.7\%). In total, only $46.7 \%$ of all innovative enterprises collaborated with other enterprises or organisations [19].

To conclude, the current state of play of business innovation activity in Lithuania shows a strong need for purposeful public policy tools ensuring persistent development of the innovative business sector. It is crucial that national innovation policy measures directly respond to the existing challenges of business innovation activity.

\section{Business Innovation Promotion: Analysis of the Lithuanian Innovation Strategy Actions}

In 2010, Lithuania approved its first innovation strategy based on holistic approach with the aim to build a creative society and create the conditions for the development of entrepreneurship and innovation. Four main objectives of innovation development were identified: (1) to accelerate Lithuania's integration into the global market; (2) to educate a creative and innovative society; (3) to develop broad-based innovation; (4) to implement a systematic approach to innovation [8].

However, the promotion of business innovation activity is not explicitly referred to as a priority in the Lithuanian Innovation Strategy ('LIS'). This can be also seen from the analysis of the strategy's implementation action plan for 2010-2013 (hereinafter - 'the Action Plan'). According to the data provided in the Figure 6, only $18 \%$ of all measures of the strategy are directly oriented towards business needs. Moreover, taking into account the actions planned for the development of innovative business sector, a percentage share indicated above would be even lower. 
Figure 6. Distribution of the LIS implementation measures by the action field (\% of all measures)

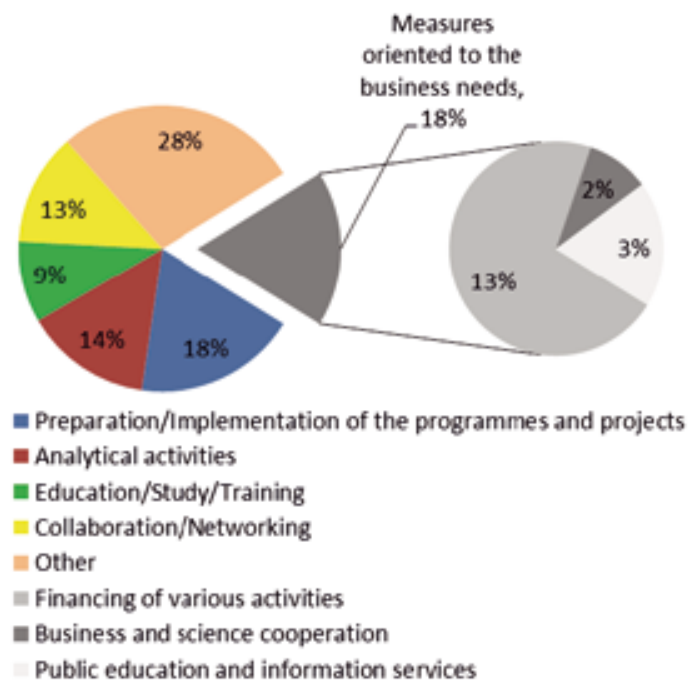

Source: calculated and compiled by the author according to the LIS action plan for 2010-2013 [11]

More specifically, the analysis shows the following distribution of all 119 LIS implementation measures by different action fields:

- 21 measures are directly oriented towards the business needs including:

- 15 measures focused on financial support to various activities (i.e. clusterisation; R\&D projects; internationalisation; protection of intellectual property rights; building of R\&D infrastructure; etc.);

- 2 measures directed to business and science cooperation;

- 4 measures for education and information services;

- Only 11 measures here are planned for the promotion of business innovation activity;

- 5 measures designed exclusively for small and medium-sized enterprises.

- In total, LTL 2.47247 billion are planned for these 21 measures (detailed distribution of financial allocations to business-focused measures is given in Table 2).

- 22 measures encompass the preparation and implementation of other programmes or strategic projects;

- 17 measures are oriented towards analytical activities, such as feasibility studies, analyses and evaluations;

- 11 measures include education, studies and training-related activities;

- 15 measures seek to promote collaboration and networking;

- 33 measures speak about other action fields. 
Table 2. Financial allocations to business-focused measures of the LIS

\begin{tabular}{|c|c|c|c|c|c|}
\hline \multirow{2}{*}{$\begin{array}{c}\text { Number } \\
\text { of } \\
\text { measu- } \\
\text { res }\end{array}$} & \multirow[b]{2}{*}{ Category } & \multirow[b]{2}{*}{ Purpose } & \multicolumn{3}{|c|}{$\begin{array}{l}\text { Funding source and amount } \\
\text { (million litas) }\end{array}$} \\
\hline & & & $\begin{array}{c}\text { State } \\
\text { budget }\end{array}$ & \begin{tabular}{|c|} 
EU \\
structural \\
funds
\end{tabular} & $\begin{array}{l}\text { Combined } \\
\text { funds }\end{array}$ \\
\hline \multirow[t]{12}{*}{15} & \multirow[t]{12}{*}{ Financing } & Clusterisation & & $\checkmark 187$ & \\
\hline & & Internationalisation & $\checkmark 2.4$ & $\checkmark 152$ & \\
\hline & & Incubation & $\checkmark 1$ & & \\
\hline & & Feasibility studies & & $\checkmark 35.37$ & \\
\hline & & R\&D projects & & $\checkmark 160$ & \\
\hline & & $\mathrm{R} \& \mathrm{D}$ infrastructure & & $\checkmark 324.7$ & \\
\hline & & Business start and development & & $\checkmark 60$ & \\
\hline & & Venture capital for SMEs & & $\checkmark 124.3$ & \\
\hline & & Technological innovation in SMEs & & $\checkmark 408.2$ & \\
\hline & & SMEs loans & & $\checkmark 707.6$ & \\
\hline & & Compensation of SMEs loan interest & & $\checkmark 104$ & \\
\hline & & Intellectual property rights & $\checkmark 15.83$ & & \\
\hline \multirow[t]{2}{*}{2} & \multirow{2}{*}{$\begin{array}{l}\text { Business } \\
\text { and science } \\
\text { cooperation }\end{array}$} & Researcher employment in SMEs & & & $\checkmark 63$ \\
\hline & & \begin{tabular}{|l|} 
Scientific solutions for business \\
(Innovation vouchers)
\end{tabular} & $\checkmark 21$ & & \\
\hline \multirow[t]{2}{*}{4} & \multirow{2}{*}{$\begin{array}{l}\text { Public } \\
\text { services for } \\
\text { business }\end{array}$} & Dissemination of information & & $\begin{array}{ll}\checkmark & 75.91 \\
\end{array}$ & \\
\hline & & Training & $\checkmark 0.16$ & $\checkmark \quad 30$ & \\
\hline \multicolumn{3}{|c|}{$\begin{array}{l}\text { Total funding to business-oriented actions: LTL } 2472.47 \text { mil- } \\
\text { lion (EUR } 716.08 \text { million) }\end{array}$} & $\begin{array}{l}40.39 \\
(11.7) \\
\end{array}$ & $\begin{array}{l}2369.08 \\
(686.13) \\
\end{array}$ & $\begin{array}{ll}63 \\
(18.25)\end{array}$ \\
\hline
\end{tabular}

Source: calculated and summarised by the author according to the LIS action plan for 2010-2013 [11]

Figure 7. Distribution of all the LIS implementation measures by their source of funding

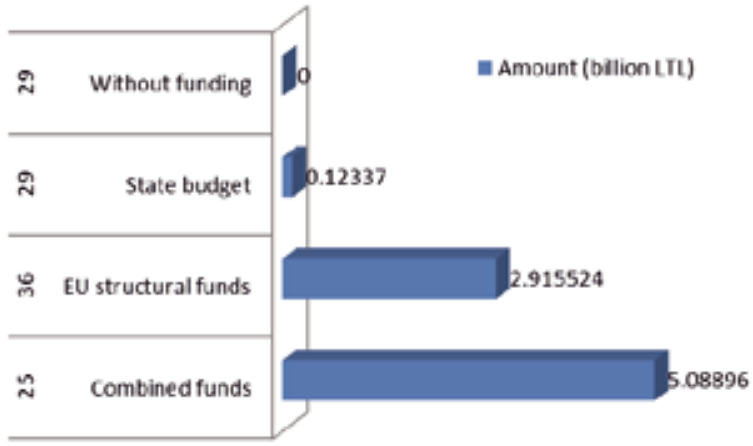

Source: calculated and compiled by the author according to the LIS action plan for 2010-2013 [11]

In total, the funding of more than LTL 8 billion (i.e. more than EUR 2 billion) is planned for the implementation of the Lithuanian Innovation Strategy for 2010-2013. By 
their funding source, all the measures are distributed as follows (Figure 7): 29 measures are funded form the Lithuanian budget; 36 measures are based on the EU structural funds for 2007-2013; 25 measures are to be financed from different funding sources (combined funds); 29 measures do not require any financial allocations.

Taking into consideration the content of the LIS implementation measures, the nature of their formulation as well as the results planned to achieve by their implementation, the following remarks can be highlighted:

- The measures planned differ widely in "size" and "weight". Some of them are vague or too broad without providing the concrete results of implementation. Moreover, not all results foreseen are measurable and their role in the innovation development is uncertain.

- Measures clearly identifying the real benefits for business enterprises engaged in innovation activity are lacking.

- There are plenty of measures (i.e. 39) related to the implementation and monitoring of already existing programmes or preparation of new feasibility studies that usually do not speak about tangible results contributing to innovation promotion.

- The promotion of business and science cooperation could be more widely expressed in this action plan. For instance, one measure is oriented towards the employment of researchers (except students) in the business sector, while the programmes of doctoral studies also should be directed towards the business needs and could be based on different schemes responding to both science and business expectations. In this case, application of the best practice of other countries (e.g. Denmark's Industrial PhD programme; Norway's Industrial $\mathrm{PhD}$ scheme; etc.) might be considered.

- $\quad$ Some measures vary significantly among the separate LIS objectives (Figure 8) and goals (for instance, the goal "to promote technological, non-technological, social and public innovation" contains 25 measures, while the other goal "to promote innovation oriented towards demand and consumers' needs", which lies under the same objective, includes only 4 measures).

Figure 8. Distribution of the measures by separate LIS objectives (\% of all measures)

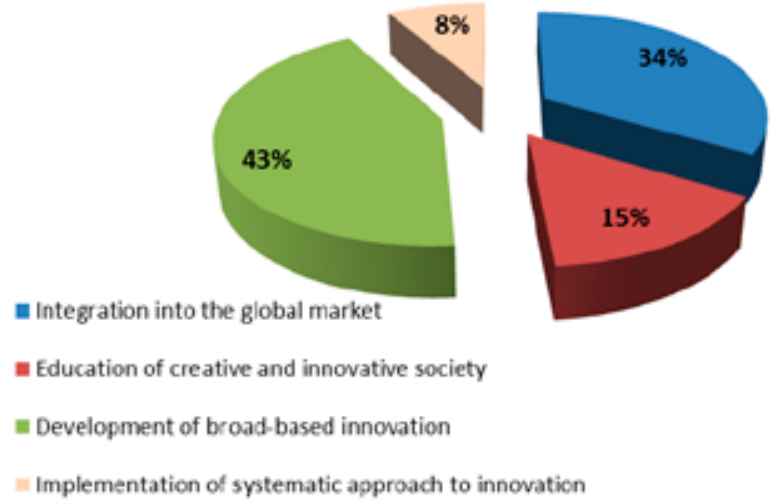

Source: formed by the author 
In general, the analysis of the LIS action plan reveals a need to reconsider a set of measures planned in different priority fields. On the one hand, the current strategic approach gives a sense of systematically integrated actions necessary for the coherent and horizontal implementation of national innovation policy. However, on the other hand, lack of attention to the real challenges facing innovation development in Lithuania can cause strategic inefficiency leading to the limited or even negative results in the long run. From this perspective, current state of business innovation activity in Lithuania should be taken into account properly.

\section{Conclusions}

The discussions in this article point at the complexity of business innovation promotion, taking the multidimensional nature of this process into account, where the wide range of innovation factors and their interactions are involved.

Based on the review of different sources, it is clear that factors of innovation activity belong to both business internal and external environments in which enterprises operate and are therefore difficult to manage. However, the purposeful and continuous public policy actions can help business reduce the existing challenges and effectively contribute to the formation of innovation-based economy.

The statistics shows that the situation of Lithuania's business innovation activity still needs to be enhanced considerably: only around one-third of all enterprises are engaged in the innovation activity, where the role of small and medium-sized enterprises is very limited; business expenditure on R\&D remains more than five times lower, compared to EU27 average; and enterprises still weakly collaborate with public research institutions.

Meanwhile, the analysis of the Lithuanian Innovation Strategy implementation actions planned for 2010-2013 showed a lack of strategic orientation towards the development of innovative business sector. Only 21 measures out of 119 are directly targeted for the business needs and only 11 of them are focused on the promotion of business innovation activity. Moreover, only $30 \%$ of all financial allocations for the implementation of this strategy are directed at business support measures. Many of the existing national innovation policy measures lack clarity and concreteness in terms of their content and implementation measurability.

Thus, the findings of this paper call for reconsideration of the existing Lithuanian Innovation Strategy implementation measures in order to more effectively promote the development of innovative business sector in Lithuania. To achieve this, the more strategic and systematic approach based on direct response to current business needs and challenges as well as on common set of business innovation factors should be applied.

\section{References}

1. Adekota A., Korsakienè R., Tvaronavičienè M. Approach to innovative activities by Lithuanian companies in the current conditions of development. Baltic Journal on Sustainability: Technological and Economic Development of Economy, 2008, 14(4): 595-611. 
2. Baležentis A., Balkienè K. Analysis of Lithuanian innovation policy priorities in the context of the European Union initiatives. Public Policy and Administration, 2011, Vol. 10, Issue 2, p. 212-230.

3. Baležentis A., Žalimaitè M. Application of expert evaluation in the analysis of innovation development factors: Assessment of Lithuanian innovative enterprises. Management theory and studies for rural business and infrastructure development, 2011, 1(25): 23-31.

4. Brown, B. Why innovation matters. Research Technology Management. Nov/ Dec2010, Vol. 53, Issue 6, p. 18-23.

5. Drucker, Peter F. Thinking Ahead. Harvard Business Review. Jan/Feb1959, Vol. 37, Issue 1, p. 25-150.

6. European Commission. Europe 2020 flagship initiative: Innovation Union. $\operatorname{COM}(2010) 546$ final.

7. European Commission. Innovation Tomorrow. Innovation papers, 2002. [accessed on 15-03-2013] <ftp://ftp.cordis.europa.eu/pub/innovation-policy/studies/studies_ innovation_tomorow.pdf>

8. Government of the Republic of Lithuania. Lithuanian Innovation Strategy for 20102020. Resolution No. 163 of 17 February 2010.

9. Jakubavičius A., Vilys M. Priority spheres in the development of a public innovation policy. Public Administration. 2009, Vol. 3/4, Issue 23/24, p76-83.

10. Kraujelytė A., Petrauskas R. Role of technology transfer in innovation process: Lithuanian innovation policy perspective. Public Policy and Administration. 2007, Vol. 19, p54-68.

11. Lithuanian Innovation Strategy Implementation Action plan for 2010-2013 [accessed on 05-03-2013] <http://www3.lrs.lt/pls/inter3/dokpaieska.showdoc_l?p_ $\mathrm{id}=383049 \&$ p_query $=\&$ p_tr2=2>

12. Melnikas B. Innovation policy and economic development: The idea of "Oazes". Management of Organizations: Systematic Research. 2003, Issue 27, p81-99.

13. Oslo Manual: Guidelines for collecting and interpreting innovation data. 2005 [accessed on 12-03-2013] <http://epp.eurostat.ec.europa.eu/cache/ITY_PUBLIC/ OSLO/EN/OSLO-EN.PDF>

14. Oslo Manual: The Measurement of scientific and technological activities. 1996 [accessed on 10-03-2013] <http://www.oecd.org/science/inno/2367580.pdf>

15. Schumpeter J. A. The Theory of economic development: An inquiry into profits, capital, credit, interest and the business cycle, 1911.

16. Statistical office of the European Union: Eurostat. Research and development expenditure. [accessed on 29-03-2013] <http://epp.eurostat.ec.europa.eu>

17. Statistical office of the European Union: Eurostat. Researchers [accessed on 29-032013] <http://epp.eurostat.ec.europa.eu>

18. Statistics Lithuania. Cooperation partners in innovation activities [accessed on 2703-2013] <http://db1.stat.gov.lt>

19. Statistics Lithuania. Development of innovation activity. 2010, Vilnius, ISSN 2029-3763.

20. Statistics Lithuania. Employees and turnover of innovative enterprises [accessed on 27-03-2013] <http://db1.stat.gov.lt> 
21. Statistics Lithuania. Innovative enterprises by economic activity. [accessed on 2703-2013] <http://db1.stat.gov.lt>

22. Stripeikis O., Ramanauskas J. Factors of organizational culture favourable to innovations. Management theory and studies for rural business and infrastructure development, 2011, 3(27): 224-230.

23. Swedish Innovation Strategy, 2012 [accessed on 20-03-2013] <http://www.government.se/content/1/c6/20/25/58/ace0cef0.pdf>

24. United Nations University. Entrepreneurship and economic development. Studies in Development Economics and Policy, 2011.

25. Vilys M., Aleksandravičius P. Modern innovation policy: priorities for technical-technological development. Public Administration. 2008, Vol. 1, Issue 17, p28-35.

\section{VERSLO INOVACIJŲ SKATINIMAS LIETUVOJE: TEORINIAI, STRATEGINIAI IR STATISTINIAI ASPEKTAI}

Santrauka. Nepakankami verslo inovacinès veiklos rezultatai Lietuvoje išryškina šiai situacijai ịtakos turinčių veiksnių analizès poreikị. Daroma prielaida, kad vienas iš galimai esminių faktorių - konkrečių ir kryptingų valdžios veiksmų verslo inovacijų skatinimo atžvilgiu stygius. Atsižvelgiant $\mathfrak{i}$ tai straipsnyje nagrinejjamas verslo inovacinès veiklos skatinimas Lietuvoje teorinių, strateginių ir statistinių duomenų analizès pagrindu.

Straipsnyje pasiūlyta teorine verslo inovacijoms įtakos turinčių veiksnių sistema, pateikta verslo inovacinès veiklos situaciją Lietuvoje atspindinčių statistinių duomenų analizė, atliktas Lietuvos inovacijų 2010-2010 metų strategijos igyvendinimo 2010-2013 metų priemonių plane nurodytų veiksmų inovacijų versle skatinimo atžvilgiu vertinimas.

Kristina BALKIENE - PhD student of Management and Administration Studies at Mykolas Romeris University. Research fields: innovation policy, entrepreneurship policy, business innovation activity.

Kristina BALKIENE - Mykolo Romerio universiteto Vadybos ir administravimo studiju doktorantė. Mokslinių tyrimų sritys: inovacijų politika, antreprenerystės politika, verslo inovacinė veikla. 